\title{
Keating Construction Dispute Resolution Handbook
}


Downloaded by [] on [26/04/23]. Copyright @ ICE Publishing, all rights reserved. 


\section{Keating Construction}

Dispute Resolution

\section{Handbook}

\section{Third edition}

By a specialist team of authors in Keating Chambers

Edited by

Dr Robert Gaitskell QC CEng 
Published by ICE Publishing, One Great George Street, Westminster, London SW1P 3AA.

Full details of ICE Publishing representatives and distributors can be found at: www.icebookshop.com/bookshop_contact.asp

First edition published 2006

Second edition published 2011

This edition 2017

Other titles by ICE Publishing:

ICE Manual of Construction Law.

V. Ramsey, A. Minogue, J. Baster and M.P. O'Reilly (eds).

ISBN 978-0-7277-4087-8

Delay and Disruption Claims in Construction, Second edition.

A. Haidar and P. Barnes. ISBN: 978-0-7277-5967-2

Dispute Boards: Procedure and Practice.

G. Owen and B. Totterdill. ISBN 978-0-7277-3508-9

www.icebookshop.com

A catalogue record for this book is available from the British Library.

ISBN 978-0-7277-6164-4

(C) Thomas Telford Limited 2017

ICE Publishing is a division of Thomas Telford Ltd, a wholly-owned subsidiary of the Institution of Civil Engineers (ICE).

All rights, including translation, reserved. Except as permitted by the Copyright, Designs and Patents Act 1988, no part of this publication may be reproduced, stored in a retrieval system or transmitted in any form or by any means, electronic, mechanical, photocopying or otherwise, without the prior written permission of the publisher, ICE Publishing, One Great George Street, Westminster, London SW1P 3AA.

This book is published on the understanding that the author is solely responsible for the statements made and opinions expressed in it and that its publication does not necessarily imply that such statements and/or opinions are or reflect the views or opinions of the publishers. While every effort has been made to ensure that the statements made and the opinions expressed in this publication provide a safe and accurate guide, no liability or responsibility can be accepted in this respect by the author or publishers.

While every reasonable effort has been undertaken by the author and the publishers to acknowledge copyright on material reproduced, if there has been an oversight please contact the publishers and we will endeavour to correct this upon a reprint.

Commissioning Editor: Michael Fenton

Production Editor: Rebecca Norris

Market Development Executive: Elizabeth Hobson

Typeset by Academic + Technical, Bristol

Index created by Laurence Errington

Printed and bound by CPI Group (UK) Ltd, Croydon CRO 4YY 
01

\section{Introduction}

Robert Gaitskell

1.1. The third edition

1.2. Overview of the forms of dispute resolution

1.3. The seven forms of dispute resolution

1.4. Plan your strategy

02

\section{Avoiding disputes}

Gaynor Chambers

2.1. Introduction

2.2. Contractual means of avoiding disputes

2.3. Effective contract management

03

When disputes arise

Paul Buckingham, Samuel Townend and Krista Lee

3.1. Overview procedure

3.3. Defending a claim: deadlines

3.4. Instructing lawyers

04

\section{Litigation}

Finola O'Farrell

4.1. Introduction

4.2. The Technology and Construction Court (TCC) system

4.3. Pre-action protocols

4.4. Commencement of proceedings

4.5. Case and costs management

4.6. Alternative dispute resolution (ADR)

4.7. Default judgment

4.8. Summary judgment

4.9. Interim payment

4.10. Interim injunction

4.11. Case management powers of the court

4.12. Disclosure

4.13. Witness statements

4.14. Expert reports

4.15. Pre-trial review (PTR) 
4.16. Trial 56

4.17. Costs 57

4.18. Part 36 offers 59

4.19. Appeals 61

05

$\begin{array}{ll}\text { Arbitration } & 63\end{array}$

Paul Buckingham

5.1. What is arbitration? 63

5.2. Advantages of arbitration 64

5.3. Disadvantages of arbitration 65

5.4. The arbitration clause 65

5.5. Commencing an arbitration 67

5.6. Multi-party claims 68

5.7. Choosing an arbitration tribunal 68

5.8. Conducting an arbitration 69

5.9. The arbitration hearing 73

5.10. The arbitration award 75

5.11. Costs 76

5.12. Challenging arbitration awards $\quad 77$

5.13. Conclusion 78

$06 \ldots \ldots \ldots \ldots \ldots \ldots \ldots \ldots$ Adjudication

Samuel Townend

6.1. Introduction 79

6.2. Statutory adjudication 80

6.3. Application of statutory adjudication 81

6.4. The technical use of adjudication 83

6.5. Construction consultant's fees 85

6.6. Rules of adjudication 86

6.7. The adjudication notice 87

6.8. Appointment of an adjudicator 89

6.9. The referral notice 91

6.10. Responding to adjudication proceedings 93

6.11. Substantive contents of a response 95

6.12. Subsequent procedures 96

6.13. The decision 97

6.14. Enforcement 97

$07 \ldots \ldots \ldots \ldots \ldots \ldots \ldots \ldots$ Mediation $\quad 99$

Robert Evans

7.1. What is mediation? 99

7.2. Why mediation works 100

7.3. Facilitative and evaluative mediation $\quad 102$

7.4. When to use mediation 103

7.5. Appointing a mediator 104

7.6. The mediation 106 
8.1. Introduction

8.2. Expert determination versus other dispute resolution processes

8.3. The question(s) to be referred to the expert

8.4. The parties' agreement to refer a question to an expert

8.5. The terms of the expert's appointment

8.6. Enforcing or challenging the process or the decision

09

Early neutral evaluation

9.1. Introduction

9.2. Key features

9.3. The aim of ENE

9.4. What does an evaluator do?

9.5. When to use ENE

9.6. Appointing an evaluator

9.7. Preparation for the evaluation

9.8. The evaluation decision/recommendation

9.9. Summary

10

International arbitration, mediation and expert determination

Robert Gaitskell

10.1. Introduction

10.2. Choosing the dispute resolution procedure

10.3. Arbitration

10.4. Mediation and early neutral evaluation

10.5. Expert determination

10.6. Conclusion

11 International dispute boards and adjudication Robert Gaitskell

12 Immediate help 
12.3. Law reporting

12.4. Reference sources

Conclusion

169

Robert Gaitskell

Index

171

viii

Downloaded by [] on [26/04/23]. Copyright @ ICE Publishing, all rights reserved. 
Foreword to the third edition
It is a pleasure to introduce this third edition of what has become an increasingly successful handbook on dispute resolution or, as the book itself emphasises, dispute avoidance - which is always the better course. But as the Latin maxim tells us, Si vis pacem, para bellum: If you want peace, prepare for war. In the present context, the aphorism becomes: If you want to avoid a formal dispute, ensure you are prepared for one, by the keeping of proper records, the serving of timely notices and making yourself familiar with all the steps that will be needed if the dispute cannot be resolved. By these means you will achieve the best outcome, whether by avoidance of the dispute or by prevailing if it becomes inevitable.

An essential element in preparing for a dispute resolution process is to know all the alternative processes so that a truly informed choice can be made when it comes to committing a client to the inevitable costs of pursuing one of the processes. Not only does this involve knowledge of the processes themselves and the way in which they interact, but also appreciating all the preliminary stages such as how to secure appropriate legal advice and whether to start by consulting a solicitor or a barrister and when this is permitted under the prevailing rules.

The backdrop to all dispute resolution is the court system in whatever jurisdiction the dispute may arise. The courts are there as the fall-back for the final resolution of any dispute that cannot be resolved by other means, including enforcement of decisions given as a result of other dispute resolution processes. The courts' functions also include the support for and enforcement of those other processes, including staying any legal proceedings brought by one party in breach of an agreement to resolve disputes by other means, whether those means are arbitration or some other process.

The full repertoire of private dispute resolution processes is here presented in separate chapters, the available techniques now numbering seven, with additional hybrid processes for international disputes involving particular combinations of processes. All these are explained and presented by individual specialists from Keating Chambers, all of whom are otherwise engaged in dealing with the same issues on a day-to-day basis and therefore able to present the latest thinking and the latest techniques in this ever-evolving world.

It is no wonder that the success of this small book has led to its successive name changes, the original Engineers' 
Dispute Resolution Handbook having become for the second edition the Construction Dispute Resolution Handbook, and now, taking account of the attraction of the work in a wider field, including oil and gas, energy, and ship and rig construction, the book has taken its proper place in the series of volumes carrying the Chambers' brand as the Keating Dispute Resolution Handbook. I warmly commend this introductory volume to all who have to consider embarking on the resolution of a dispute in any of these related technical fields and, of course, also to those about to sign contracts for such works who may find a dispute looming rather earlier than expected, and have an urgent need to be prepared for a dispute, while hoping it can be avoided. Knowledge of what may be involved is the key to achieving the best outcome.

Professor John Uff CBE QC FREng

Keating Chambers, London Emeritus Professor of Engineering Law, King's College London 
Foreword to the second edition
The success of the first edition of this work, Engineers' Dispute Resolution Handbook, is not a surprise. The book covers the complete spectrum of dispute resolution expertise required by engineers and other professionals involved in substantial construction projects, which is otherwise available only in separate and unconnected texts. As pointed out in the Foreword to the first edition, the challenge is not simply the effective use of one dispute resolution procedure, but making effective use of the whole range of procedures available.

The basic procedures available now number at least six, all of which are well covered in this work. But it will be found that parties are quite capable of 'inventing' other procedures with new names which, however, invariably turn out to be one of the existing systems, or perhaps a combination of these, repackaged for the particular needs of the case. An example of this is a 'conciliation' procedure introduced into a number of high-value contracts in Taiwan which required disputes to be conciliated by a panel, but if the parties did not reach settlement, the panel was to issue a decision which was contractually binding until a final decision by a court or arbitrator, following the UK adjudication model. The moral is that the principles remain the same, whatever the label.

In deciding how particular disputes should be resolved, the choices facing the parties are: (1) an initial choice between state court or private dispute resolution; and if the latter, (2) a choice between procedures supported by court powers such as arbitration or adjudication and ad hoc procedures such as mediation, expert determination and early neutral evaluation (ENE); and then (3) a choice as to the extent to which a decision or result is to be binding. It is perhaps this last element that can surprise the non-lawyer, as it is the judgment of the High Court that is most likely to be reversed on appeal, and, conversely, the relatively informal decision in an expert determination is least likely to be open to challenge in any forum. And although adjudication is, in theory, binding only until the dispute is 'finally determined' in another tribunal, the reality is that adjudication is about cash flow and, depending on your source of statistics, something well in excess of $90 \%$ of adjudication decisions are not challenged further. At the other end of the scale, mediation and ENE create no binding result unless the parties enter into a binding contractual settlement as a result. Even here the courts are beginning to entertain limited 
challenges, but the processes themselves remain relatively risk free.

One might ask why all these procedures are needed and why could we not return to the old days when the engineer was king (see Foreword to the first edition). One answer is that the world inevitably moves forward and lawyers and contract draftsmen will be dragged along with the rest of humanity. Another answer is that contracts, and therefore the disputes that they generate, are vastly more complex today than at any time in the past, and call for a corresponding spread of remedies such as those described in this work. Another significant new facet of modern dispute resolution techniques is that they are infinitely more available than at any time in the past. A mere 20 years ago the only remedy available to a contractor under an Institution of Civil Engineers (ICE) Form of Contract who was dissatisfied with the engineer's certification was to refer the matter back to the (same) engineer, who was then given 3 months to reconsider and, if he thought fit, to affirm his original decision. Compare this to the current availability of adjudication 'at any time' or, if preferred, arbitration or any other agreed method of resolution, also at any time. However, it may be that this abundance of availability now carries with it the danger that parties may be precipitated into a formal dispute resolution process earlier than is necessary, and before steps have been taken that might reduce or even avoid the dispute. Hence the importance of dispute avoidance (a phrase that would not have been understood in the past) and the systematic consideration of the steps to be taken when a potential dispute looms. Both these subjects are well covered in this book.

While the basic principles remain unaltered, this edition has updated the law and practice in a number of respects, which are reviewed in Chapter 1 . The book has rightly attracted a wide following, and will become one of the standard pieces of equipment needed by those whose business it is to see engineering disputes properly resolved.

Professor John Uff CBE QC FREng

Keating Chambers, London

Emeritus Professor of Engineering Law, King's College London 
Foreword to the first edition
There was a time when the engineer was king. In those days disputes were, in the first place, settled by the engineer acting as quasi-arbitrator, usually following his own decision as certifier. Sometimes he changed his mind, and only rarely did a dispute get beyond the contractual mechanism and out into the world of arbitration. And even then the invariably sole arbitrator would be another engineer, who could be expected to look at the issues in the same way as the original engineer. Partly for these reasons it was rare for a formal dispute even to arise. Most matters would be dealt with by informal discussion, with the engineer certifying what he thought was appropriate. Engineers in those days were said to command great respect.

But all was not necessarily well in the world of engineering contracts, even in the heady days of 19th century industrialisation. Isambard Kingdom Brunel is still revered as one of the greatest engineering geniuses. But his treatment of contractors shows him in another light. Brunel's appalling treatment of William Ranger, one of the contractors for the Great Western Railway, is fully documented in the report in House of Lords Cases (1854), volume V, page 72. Ranger had taken on a series of contracts, including that for the Avon Bridge, which was to be constructed in stone from the tunnels and cuttings eastward of the bridge. Ranger complained that he was deceived by reports as to the nature of the rock, which proved to be much harder than stated. When the project inevitably slowed down, Brunel took the work out of Ranger's hands and charged him with the additional cost of completion as well as delay penalties, eventually driving him to ruin. Ranger's final plea to the House of Lords that Brunel was a substantial shareholder in the company, and for that reason his decision could not be binding, was dismissed with a mixture of disbelief and regret that such a point should be taken. From that stage on, for more than a century the engineer remained king.

Ironically, it was not the great power wielded by the engineer which eventually led to his demise, but something quite different. By the 1970s there was general dissatisfaction in the construction industry that both engineers and architects, as the principal certifiers of cash flow to contractors, were no longer the independent spirits they once had been. They tended always to err in the employer's favour, rejecting claims which had then to be pursued in arbitration. Sometimes the engineer reacted cautiously, through fear of being sued himself for 
overcertification; and sometimes he was under pressure to avoid exceeding budgetary limits of which the contractor was unaware. Yet under the Institution of Civil Engineers (ICE) Standard Form Conditions of Contract, and many others, arbitration against the engineer's decision could not generally be pursued until after completion of the works, leaving the engineer in sole charge of the contractor's cash flow.

In the case of the ICE Conditions of Contract, the first sign of change began with the seemingly innocuous introduction of 'conciliation' as an alternative to the engineer's decision. One thing rapidly led to another, the next step being a reduction in the 3 months allowed for the engineer's decision, to a more familiar 1 month.

This was followed by the groundbreaking introduction of arbitration available at any time, without the necessity of waiting for completion. This was the situation at the time the Housing Grants, Construction and Regeneration Act came onto the scene in 1996.

No one quite predicted what would be the effect of the statutory adjudication on the construction industry. The ICE initially attempted to preserve the traditional but reduced role of the engineer by relabelling the initial 'dispute' as a 'matter of dissatisfaction' so that the contractor remained bound to submit the matter to the engineer before a dispute could arise for the purposes of adjudication. This device was considered by some to be legally ineffective, and by others to be contrary to the spirit of the new Act. At all events, it was soon abandoned, leaving hardly a trace of the former regime. The latest 2005 amendments to the main ICE Conditions of Contract, mirrored in all the other ICE forms, thus presents the parties (it must never be forgotten that the employer may initiate disputes) with a seemingly bewildering choice between negotiation, mediation, adjudication, arbitration or even litigation. All these options must now be packed into any form of construction contract, and they present their own challenge to the parties. Rather than searching for a remedy within the inadequate procedures provided up to the 1970s, parties wishing to pursue a genuine dispute now have an embarrass de richesses in terms of available channels of resolution. The danger thereby created is that the would-be claimant may fail to identify the quickest and cheapest means by which the dispute may be resolved. The prospect of multiple concurrent resolution procedures carries with it the alarming possibility, if not probability, of multiple costs, all of which have to be 
paid by someone. None of the dispute reformers have yet devised a way of reducing the cost of legal services or the disruption that a formal dispute procedure can cause to normal economic activity.

So there is the challenge that dispute resolution now presents to engineers, contractors, lawyers and all those involved in engineering and construction disputes: how most effectively to make use of the huge variety of available techniques and procedures, and particularly whether to use the procedures singly or in combination. That is why this handbook is now invaluable as a source of essential expertise in making these unavoidable choices. Whatever choice is made, the initiating party inevitably commits to a particular course; and even if that course can be switched before reaching its conclusion, costs will have been incurred which must be paid. Parties must now decide, at the outset of a dispute, their particular strategic route to achieving satisfactory resolution. This presents choices and challenges not dissimilar to those of programming and managing the construction work itself, and involves no less serious outlay of expenditure.

For the task of overcoming these novel hurdles, I am delighted to commend this handbook to anyone embarking on dispute resolution, whether as a theoretical study, in preparation for disputes to come, or in support of actual disputes that need immediate decisions and commitment to a particular course of action. The work is written by a team of specialists who can offer practical help and guidance in all the intricate stages described, and particularly in making the strategic decisions that will ultimately determine whether the dispute is resolved satisfactorily or not. Dispute resolution is no longer to be embarked upon without the guidance offered in this handbook.

Professor John Uff CBE QC FREng

Keating Chambers 
Downloaded by [] on [26/04/23]. Copyright @ ICE Publishing, all rights reserved. 


\section{List of contributors}

Robert Gaitskell QC

Call 1978, Silk 1994

$\mathrm{PhD}$ (King's College London)

BSc (Engineering), AKC, Chartered Engineer

FIET, FIMechE

FCIArb, Former Recorder. Former Vice President of the IEE

Former Senator of the Engineering Council, CEDR

Accredited Mediator

Adjudication and Arbitration Panel of the IET

Dr Gaitskell is a practising Queen's Counsel in Keating Chambers, London, specialising in engineering disputes, often of an international nature. He acts as arbitrator, adjudicator, mediator, dispute board chair and member, and expert determinator. A Chartered Engineer, a former Vice President of the Institution of Electrical Engineers (IEE/IET) and a former Senator of the Engineering Council, he is a Fellow of both the IET and the Institution of Mechanical Engineers. A part-time judge, a bencher of Gray's Inn, a CEDR Accredited Mediator and a Fellow of the Chartered Institute of Arbitrators, Dr Gaitskell is also the Chairman of the Joint IET/IMechE Committee on Model Forms, which produces the $\mathrm{MF} / 1-4$ suite of standard-form contracts for the creation of power stations and similar works. $\mathrm{His} \mathrm{PhD}$ was on engineering standard-form contracts.

\section{Finola O'Farrell QC}

Call 1983, Silk 2002

BA(Hons) (Law) (Dunelm)

Recorder and Deputy High Court Judge

Accredited Mediator and Adjudicator

\section{Robert Evans}

Call 1989

MA (Cantab), LLB (Lond)

Chartered Engineer

FICE, FCIArb, MHKIE

\section{Jonathan Lee QC}

Call 1993, Silk 2015

BEng, MIET

\section{Paul Buckingham}

Call 1995

BSc (Chemical Engineering)

Chartered Engineer

FIChemE

Adjudication and Arbitration Panel of the IChemE 


\section{Richard Coplin}

Call 1997

BA (Oxon)

Gaynor Chambers

Call 1998

BSc

Krista Lee

Call 1996

MA, BCL (Oxon), BSc (Open)

Chartered Arbitrator

Accredited Adjudicator

AMIMechE, FCIArb

\section{Samuel Townend}

Call 1999 (Northern Ireland 2014)

MA (Cantab)

Accredited Adjudicator, Mediator and Dispute Board

Panellist 